\title{
THE EFFECTS OF PARATHYROID EXTRACT ON RENAL FUNCTION IN MAN
}

\author{
By HOWARD H. HIATT ${ }^{1}$ AND DAVID D. THOMPSON 2 \\ (From the National Institute of Arthritis and Metabolic Diseases, National Institutes of Health, \\ Public Health Service, U. S. Department of Health, Education and Welfare, Bethesda, Md.)
}

(Submitted for publication August 30, 1956; accepted December 13, 1956)

The evidence that parathyroid extract acts directly on bone appears conclusive (1-3). Whether the extract exerts an effect on the kidney, however, has not been so convincingly answered. It has long been known that an increase in urinary phosphate follows the administration of parathyroid extract $(4,5)$, but the mechanism of the phosphaturia has not been clearly elucidated.

Although the osteoclastic action of parathyroid hormone could effect an increase in urinary inorganic phosphate, it could not simultaneously produce the hypophosphatemia observed in patients with hyperparathyroidism. Inhibition by the hormone of the renal mechanism for conserving phosphate, on the other hand, would account for both a rise in urinary and a fall in plasma phosphate.

Our studies demonstrate that a depression of the maximal renal tubular reabsorptive capacity for phosphate follows the administration of parathyroid extract, although in normal subjects prolonged treatment is required before such an effect is demonstrable.

\section{SUBJECTS AND METHODS}

Forty studies were carried out in nine of the normal subjects, the three patients with post-thyroidectomy hypoparathyroidism and the hyperparathyroid male described in the previous paper (6). The experimental procedures have been outlined (6)..$^{3}$ All of the experiments were performed with the patients in the postabsorptive state.

Four lots of commercial (Eli Lilly \& Company) parathyroid extract were used. Each lot was shown to be

\footnotetext{
1 Present address: Department of Medicine, Harvard Medical School and Beth Israel Hospital, Boston, Mass.

2 Present address : Department of Physiology, Cornell Medical College, New York, N. Y.

8 The following abbreviations will be employed: GFR, glomerular filtration rate; RPF, effective renal plasma flow; $\mathrm{C}_{\mathrm{In}}$, inulin clearance; $\mathrm{C}_{\mathbf{P \Delta B}}$, para-amino-hippurate clearance; $\mathrm{Tm}$, maximal renal tubular transport rate; $\mathrm{PTH}$, parathyroid extract; $\mathrm{Ca}$, calcium; $\mathrm{P}$, inorganic phosphate.
}

effective as demonstrated by a rise in serum $\mathrm{Ca}$ in at least one subject. Dosage is expressed in U.S.P. units, as assayed by the manufacturer. When given intravenously the hormone was usually administered over a period of 4 to 8 minutes. For the more prolonged studies it was given subcutaneously at 6 to 12 hourly intervals, except where otherwise indicated.

To study the effects of PTH on TmP, buffered sodium phosphate, $\mathrm{pH} 7.40$, was infused until conditions of renal tubular saturation were assured. Simultaneous with the intravenous administration of PTH a sustaining infusion was begun containing, in addition to inulin and $\mathrm{PAH}$, an amount of sodium phosphate calculated to maintain as constant as possible the elevated plasma $\mathbf{P}$ level. Thus, observations of the influence of PTH on TmP were permitted without the possible interference of rapidly changing plasma levels.

\section{RESULTS}

Acute effects of intravenous parathyroid extract at endogenous levels of plasma $P$

A rise in urinary phosphate occurred immediately following the intravenous administration of 200 to 1,000 units of PTH both to normal (Figure 1 ) and to hypoparathyroid (Figure 2) subjects. A typical study in a normal subject is outlined in Table I, while data from studies in three normal subjects are summarized in Table II. In two of the normal individuals, C. H., and J. N., the rise in urinary $\mathrm{P}$ occurred as a result of an increase in filtered $P$, which in turn, was caused by an increase in GFR. Phosphate reabsorption was increased in one subject and unchanged in the other. In the third normal individual, E. E., the increase in excreted $P$ could be accounted for by a decrease in tubular reabsorption of $\mathrm{P}$ (Table II). No change in serum calcium was observed during the 2 to 4 hours following the administration of PTH. Flushing frequently followed the intravenous administration of PTH, and transient headache was an occasional complaint. A mild and brief tachycardia often occurred, but no changes in temperature or blood pressure were observed. There was 


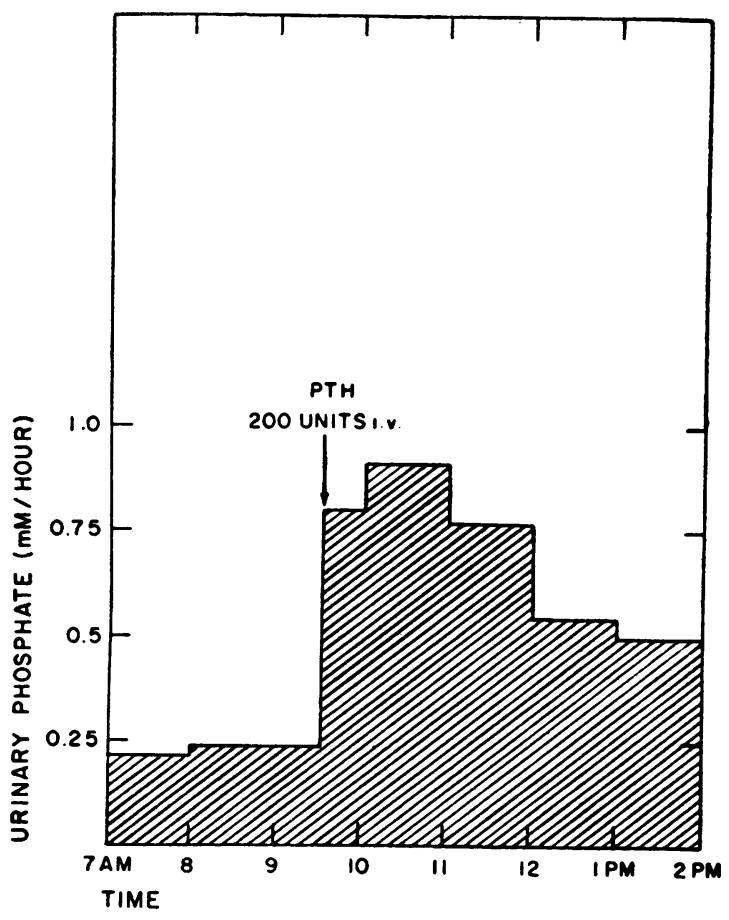

Fig. 1. Urinary Phosphate Excretion Before and Following the Intravenous Administration of 200 Units of Parathyroid Extract to R. H., a 24-YearOld Normal Female

no evidence of sensitization or resistance, even in subjects who received several injections over a period of twelve months.

Acute effects of intravenous parathyroid extract under conditions of phosphate loading

As was noted at endogenous plasma $P$ levels, no constant change in renal tubular reabsorption of $P$ resulted from the administration of $\mathrm{PTH}$ to subjects receiving $P$ infusions (Table III). If in the study summarized in Table III one selects two periods with comparable levels of plasma $\mathrm{P}$, e.g., the 6th, before the administration of PTH, and the 7th, after PTH was given, one notes that after $\mathrm{PTH}$ the excretion of $\mathrm{P}$ is increased. The rise in urinary $\mathrm{P}$ is ascribable to an increase in filtered $\mathrm{P}$, the reabsorbed $P$ remaining unchanged. Similar findings were noted in nine studies in five normal subjects (Table IV). The levels of TmP following the administration of PTH did not differ significantly from those seen prior to the administration of the hormone (Figure 3). D. F., who showed the greatest fall in $\mathrm{TmP}$ following $\mathrm{PTH}$,

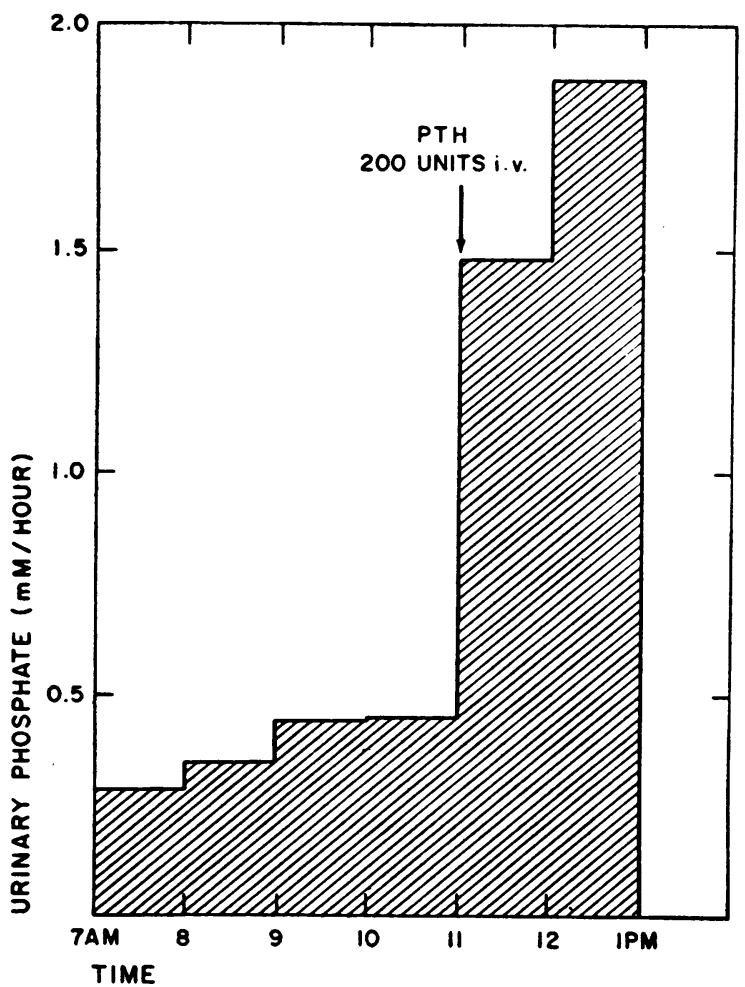

Fig. 2. Urinary Phosphate Excretion Before and Following the Intravenous Administration of 200 Units of Parathyroid Extract to L. D., a 52-YearOld Female with Post-Operative HypoparathyroidISM

was unique among the subjects studied in that spontaneous variations of his $\mathrm{TmP}$ of similar magnitude were observed on occasions when no medication was given. With but one exception a rise in GFR followed the intravenous administration of PTH, and on all occasions a striking rise in renal plasma flow was observed (Table IV). In almost all normal subjects the rise in GFR was adequate to account for the observed increase in $P$ excretion.

In the hypoparathyroid subjects, on the other hand, the rise in urinary $P$ which followed the administration of $\mathrm{PTH}$ resulted not only from an increase in filtered $P$, but from a striking diminution in the reabsorbed $\mathrm{P}$ as well (Table V). A fall in $\mathrm{TmP}$ was seen in all three hypoparathyroid subjects, although in A. W. a negligible decrease in response to $\mathrm{PTH}$ was observed on one occasion (Figure 4). The same slight but consistent rise in GFR and striking increase in RPF noted in 
TABLE I

EFFECTS OF INTRAVENOUS PARATHYROID EXTRACT ON RENAL FUNCTION AT ENDOGENOUS PLASMA PHOSPHATE LEVELS

\begin{tabular}{|c|c|c|c|c|c|c|}
\hline $\begin{array}{c}\text { ELAPSED } \\
\text { TIME } \\
\text { Min. }\end{array}$ & \multirow{2}{*}{$\begin{array}{c}\text { C PAH } \\
\text { ml / min. }\end{array}$} & $\begin{array}{c}C_{\text {IN }} \\
\mathrm{ml} / \mathrm{min} .\end{array}$ & $\begin{array}{c}\text { PLASMA } \\
\text { MM/ml. }\end{array}$ & \multicolumn{3}{|c|}{ P H O S P H A T E } \\
\cline { 5 - 7 } & & $\begin{array}{c}\text { FILTERED } \\
\text { MM/min. }\end{array}$ & $\begin{array}{c}\text { EXCRETED } \\
\text { MM/min. }\end{array}$ & $\begin{array}{c}\text { REABSORBED } \\
\text { M/min. }\end{array}$ \\
\hline $82-106$ & 535 & 122 & 1.01 & 123 & 8 & 115 \\
$106-123$ & 518 & 108 & 1.04 & 113 & 7 & 106 \\
$123-152$ & 458 & 106 & 1.03 & 109 & 6 & 103 \\
$152-189$ & 838 & 138 & 1.00 & 138 & 20 & 118 \\
$189-217$ & 825 & 130 & 0.96 & 125 & 24 & 101 \\
\hline
\end{tabular}

J. N., 22 yee old normal mole.

Sustaining inulia infusion begun at 51 min.

155 - 160 min, 1000 USP unirs of perathyroid extroet i.r.

TABLE II

ACUTE EFFECTS OF INTRAVENOUS PARATHYROId EXTRACT AT ENDOGENOUS PLASMA PHOSPHATE LEVELS IN NORMAL INDIVIDUALS

\begin{tabular}{|c|c|c|c|c|c|c|c|c|c|c|c|c|c|}
\hline \multirow{3}{*}{ Sebjiect } & \multirow{3}{*}{$\begin{array}{l}\text { Uhirs } \\
\text { of } \\
\text { Extroct }\end{array}$} & \multirow{2}{*}{\multicolumn{2}{|c|}{$\begin{array}{l}C_{\text {PAH }} \\
\text { - } 1 / \text { min. }\end{array}$}} & \multirow{2}{*}{\multicolumn{2}{|c|}{$\begin{array}{c}C_{I N} \\
m l / m i n .\end{array}$}} & \multirow{2}{*}{\multicolumn{2}{|c|}{$\begin{array}{l}\text { Plosmio } P \\
\mu M / m l\end{array}$}} & \multicolumn{6}{|c|}{ Phesphere M/lmin. } \\
\hline & & & & & & & & \multicolumn{2}{|c|}{ Filbered } & \multicolumn{2}{|c|}{ Excretiod } & \multicolumn{2}{|c|}{ Reclocerbed } \\
\hline & & Before & After & Before & After & Before & Afier & Before & After & Before & Afror & Before. & Afree \\
\hline C.H. & 800 & 550 & 674 & 121 & 145 & 1.12 & $1: 27$ & 136 & 184 & 2 & 15 & 134 & 169 \\
\hline E.E. & 800 & 620 & 930 & 130 & 131 & 1.08 & 1.06 & 140 & 139 & 3 & 18 & 137 & 121 \\
\hline J.M. & 1000 & 502 & 832 & 112 & 134 & 1.03 & 0.98 & 115 & 131 & 7 & $\boldsymbol{2}$ & 100 & 100 \\
\hline
\end{tabular}

TABLE III

EFFECTS OF INTRAVENOUS PARATHYROID EXTRACT ON RENAL FUNCTION DURING PHOSPHATE LOADING

\begin{tabular}{|c|c|c|c|c|c|c|c|c|}
\hline \multirow{2}{*}{ Period } & \multirow{2}{*}{$\begin{array}{l}\text { Elepeed } \\
\text { Time } \\
\text { min. }\end{array}$} & \multirow{2}{*}{$\begin{array}{l}\text { Urine } \\
\text { Flow } \\
\text { m/ min. }\end{array}$} & \multirow{2}{*}{$\begin{array}{l}\text { CPAH }_{\text {PH }} \\
\mathrm{ml} / \min .\end{array}$} & \multirow{2}{*}{$\begin{array}{c}C_{\text {IN }} \\
\mathrm{ml} / \mathrm{min} .\end{array}$} & \multirow{2}{*}{$\begin{array}{c}\text { Plosmo } \\
P \\
\mu M / m l\end{array}$} & \multicolumn{3}{|c|}{ Phosphate $\mu$ H/min. } \\
\hline & & & & & & Filtered & Excreted & Reabsorbed \\
\hline \multicolumn{9}{|c|}{$0 \quad$ Inulin, PAH intusion bequn. } \\
\hline 1 & $41-59$ & 5.45 & 538 & 142 & 1.09 & 155 & 4 & 151 \\
\hline 2 & $59-75$ & 8.00 & 500 & 135 & 1.07 & 144 & 4 & 140 \\
\hline \multicolumn{9}{|c|}{ Inulin, PAH, buffered sodium phosphate infusion begun. } \\
\hline 3 & $109-139$ & 8.90 & 543 & 140 & 2.16 & 302 & 92 & 210 \\
\hline 4 & $139-170$ & 5.00 & 502 & 142 & 2.52 & 358 & 152 & 206 \\
\hline 5 & $201-221$ & 4.85 & 463 & 130 & 3.53 & 459 & 262 & 197 \\
\hline 6 & $221-243$ & 3.18 & 500 & 141 & 4.02 & 566 & 329 & 237 \\
\hline \multicolumn{9}{|c|}{$\begin{array}{l}\text { Meinfencace inulin, PAH, phosphote infusion begun. } \\
200 \text { USP units of porethyroid extrect i.v. }\end{array}$} \\
\hline 7 & $279-301$ & 3.45 & 652 & 152 & 4.15 & 625 & 386 & 239 \\
\hline 8 & 301 - 319 & 256 & 591 & 144 & 4.10 & 590 & 348 & 212 \\
\hline
\end{tabular}

C.H. 17- yeer old norwal male. 
TABLE IN

ACUTE EFFECTS OF INTRAYENOUS PARATHYROID EXTRACT ON RENAL FUNCTON IN MORUAL SUBAECTS

\begin{tabular}{|c|c|c|c|c|c|c|c|c|c|c|c|}
\hline \multirow[b]{2}{*}{ Dote } & \multirow[b]{2}{*}{ Subjoet } & \multirow{2}{*}{$\begin{array}{l}\text { Uhirs } \\
\text { of } \\
\text { Exprect }\end{array}$} & \multicolumn{3}{|c|}{$C_{\text {PAH }}$} & \multicolumn{3}{|c|}{$c_{\omega}$} & \multicolumn{3}{|c|}{$\operatorname{TAP}$} \\
\hline & & & 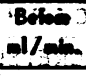 & $\begin{array}{l}\text { Ahor } \\
\text { d / mina }\end{array}$ & $\begin{array}{l}\text { Porcent } \\
\text { OCnence }\end{array}$ & 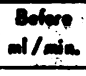 & $\begin{array}{l}\text { Afher } \\
\text { ol/mino. }\end{array}$ & $\begin{array}{l}\text { Poreent } \\
\text { Chenge }\end{array}$ & 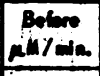 & 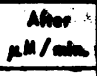 & $\begin{array}{l}\text { Poveont } \\
\text { Chenge }\end{array}$ \\
\hline $3 / 25 / 54$ & C. H. & 200 & 10 & 670. & $\operatorname{ta} 11$ & 149 & 149 & & 190 & 215 & +13 \\
\hline $4 / 6 / 54$ & C. $\mathrm{H}_{0}$ & 200 & $\mathrm{sen}$ & 620 & +24 & 138 & 140 & +7 & 217 & 241 & +11 \\
\hline $7 / 13 / 54$ & C. B. & 500 & $76^{6}$ & 265 & +13 & $151^{16}$ & 164 & +9 & 138 & 145 & $+s$ \\
\hline $9 / 7 / 54$ & $C_{N}$ & 500 & 501 & 010 & int $\mathbf{M}$ & 135 & 148 & +10 & $25 y$ & 204 & -15 \\
\hline $5 / 25 / 54$ & $E_{.} E_{0}$ & 900 & 627 & 1908 & +67 & 135 . & 153 & +13 & 169 & 200 & +23 \\
\hline $6 / 10 / 54$ & J. $\mathrm{N}$. & 1000 & 475 & 725 & +53 & 106 & 118 & \pm 11 & 17 & 157 & -11 \\
\hline $6 / 22 / 54$ & d. $\boldsymbol{K}_{0}$ & 1000 & & & & 124 & 137 & +10 & 176 & ics & +5 \\
\hline $3 / 11 / 55$ & D. F. & 500 & 30. & 620 & $+\infty$ & 91 & $n$ & $\$ 0$ & $\boldsymbol{n}$ & $n$ & -28 \\
\hline $3 / 31 / 55$ & E. P. & 500 & 597 & 241 & +3 & \% & 1110 & +23 & $\varphi$ & 120 & +23 \\
\hline
\end{tabular}

normal subjects occurred in the hypoparathyroid patients (Table VI).

The acute administration of PTH had no discernible immediate effect on plasma calcium or potassium or on urinary calcium in any of the subjects.

\section{Effects of prolonged treatment with parathyroid extract}

Hyperparathyroidism was induced in five normal subjects on six occasions and in two hypoparathyroid patients by the administration of 1,800 to 4,500 units of extract over periods of 60 to 120 hours. In all subjects hypercalcemia, hypophosphatemia, and an increase in urinary calcium and phosphate were observed (Table VII). Two subjects complained of mild skeletal pain, anorexia, polydipsia, polyuria, and constipation.

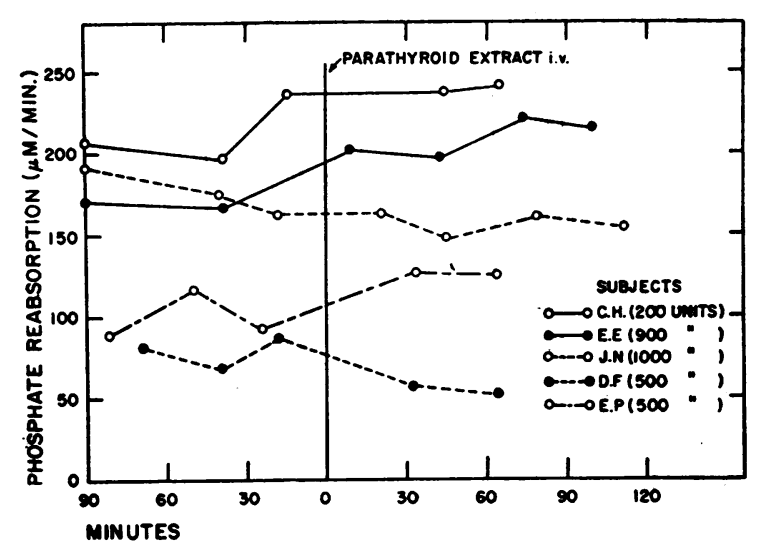

Fig. 3. Variations in TyP in Five Normal Subjects Before and Following the Intravenous AdMinistration of Parathyoid Extract
These symptoms, as well as the chemical abnormalities rapidly disappeared after discontinuation of the hormone.

The hyperparathyroid state was characterized by a depression of $\mathrm{TmP}$ in both normal (Table VIII) and hypoparathyroid (Table IX) subjects. The fall in TmP ranged from 27 to 64 per cent below control levels (Table $\mathrm{X}$ ). In W. R. on one occasion $(5 / 6 / 55)$ the $T m P$ was reduced by parathyroid extract to the level observed in the only patient with spontaneous hyperparathyroidism studied. The latter, a 72-year-old male with a plasma Ca of $14.05 \mathrm{mg}$. per $100 \mathrm{ml}$. and a plasma $\mathrm{P}$ of $0.53 \mu \mathrm{M}$ per $\mathrm{ml}$. was found to have a TmP of $26 \mu \mathrm{M}$ per minute.

The effect of the prolonged administration of parathyroid extract on $\mathrm{C}_{\mathrm{In}}$ and on $\mathrm{C}_{\mathbf{P A B}}$, in contrast to the results in the acute studies, was inconstant (Table X).

Renal function studies were carried out in a hypoparathyroid patient in the untreated state (plasma Ca, $7.10 \mathrm{mg}$. per cent; $\mathrm{P}, 1.42 \mu \mathrm{M}$ per $\mathrm{ml}$.), in an "isoparathyroid" state, following the daily administration of 100 units of extract for 5 days (plasma $\mathrm{Ca}, 10.05 ; \mathrm{P}, 1.10$ ), and in a hyperparathyroid state, following the daily administration of 900 units of extract for 3 days (plasma $\mathrm{Ca}, 12.90 ; \mathrm{P}, 0.68)$. Average $\mathrm{TmP}$ values of 170,150 , and $70 \mu \mathrm{M}$ per minute, respectively, were found at these times (Figure 5). In a similar series of studies in a second hypoparathyroid subject, B. C., a progressive lowering of $\mathrm{TmP}$ with increasing doses of extract was again noted (Table XI). Of interest is the fact that 100 units of parathyroid extract daily for 3 days served to 
TABLE V

ACUTE EFFECTS OF PARATHYROID EXTRACT ON RENAL FUNCTION IN HYPOPARATHYROIDISM

\begin{tabular}{|c|c|c|c|c|c|c|}
\hline \multirow{2}{*}{$\begin{array}{l}\text { ELAPSED } \\
\text { TUME } \\
\text { Mias }\end{array}$} & \multirow[b]{2}{*}{$\begin{array}{l}\text { C PAH }_{\text {PAH }} \\
\mathrm{ml} / \text { min. }\end{array}$} & \multirow[b]{2}{*}{$\underset{m l / \text { min. }}{C_{\text {IN }}}$} & \multirow[b]{2}{*}{$\begin{array}{c}\text { PLASMA } P \\
n M / m i\end{array}$} & \multicolumn{3}{|c|}{ PHOSPHATE } \\
\hline & & & & $\begin{array}{l}\text { FILTERED } \\
\mu \mathrm{M} / \mathrm{min} .\end{array}$ & $\begin{array}{l}\text { EXCRETED } \\
\mu M / \text { min. }\end{array}$ & $\begin{array}{c}\text { REABSORBED } \\
\mathrm{n} / \mathrm{h} / \mathrm{min} .\end{array}$ \\
\hline $77-97$ & 345 & 80.0 & 2.26 & 181 & 79 & 102 \\
\hline $97-116$ & 316 & 73.0 & 2.60 & 190 & 96 & 94 \\
\hline $116-136$ & 315 & 75.5 & 3.00 & 226 & 116 & 110 \\
\hline $159-192$ & 711 & 840 & 2.80 & 235 & 17 & 58 \\
\hline $192-216$ & 625 & 90.0 & 2.57 & 231 & 183 & 48 \\
\hline
\end{tabular}

L D., 52 yeer old femole, post - operotive hypoporethyroidism.

Centinuous infusion of buffered sodium phosphote and imulia.

137 - 145 min., Porethyroid extroct, (Lilly no. 628857), 500 USP units i.v.

lower B. C.'s plasma $\mathrm{P}$ and TmP without altering the level of plasma $\mathrm{Ca}$. Hyperparathyroidism was induced in this subject by intermittent intravenous administration of extract. ${ }^{4}$ This was the only one of the prolonged studies reported in hypoparathyroid patients in which PTH was given by other than the subcutaneous route. D. F. and W. R., two normal subjects, received three successive daily infusions, each containing 1,500 units of extract, and each given intravenously over a sixhour period. No effect on plasma $\mathrm{Ca}$ or $\mathrm{P}$ or on $\mathrm{TmP}$ (measured 15 hours after the last infusion of PTH) was observed. In W. R., an equal quantity of the same lot of hormone given in repeated subcutaneous injections over a similar period produced marked hyperparathyroidism (Table VII).

\section{DISCUSSION}

Two explanations have been offered for the increase in urinary phosphate usually observed following the administration of parathyroid extract. The evidence supporting these hypotheses, an increase in the load of phosphate filtered through the kidney, on the one hand, and a diminution in the tubular reabsorption of phosphate, on the other, has been summarized by Bartter (8). The

\footnotetext{
4 The fall in $C_{I n}$ in this subject in the hyperparathyroid state was believed ascribable to mild congestive heart failure, a state known to be accompanied by a reduced GFR (7). Digitalis, with which she had been treated for signs of failure noted one year previously, had been omitted prior to the administration of parathyroid extract.
}

rise in filtered phosphate has been ascribed to an increase in glomerular filtration rate, to a rise in plasma phosphate, or to both (9-11). Indeed, the demonstration that phosphaturia follows the administration to animals of formalin-inactivated (as assayed by its effect on serum calcium) parathyroid extract has been interpreted as indicating that the observed increase in urinary phosphate is an artifact ascribable to some non-hormonal component of an exceedingly heterogeneous preparation (12).

Our data indicate that the phosphaturia seen immediately following the intravenous administration of the extract to normal individuals is the result of an increase in GFR with a consequent

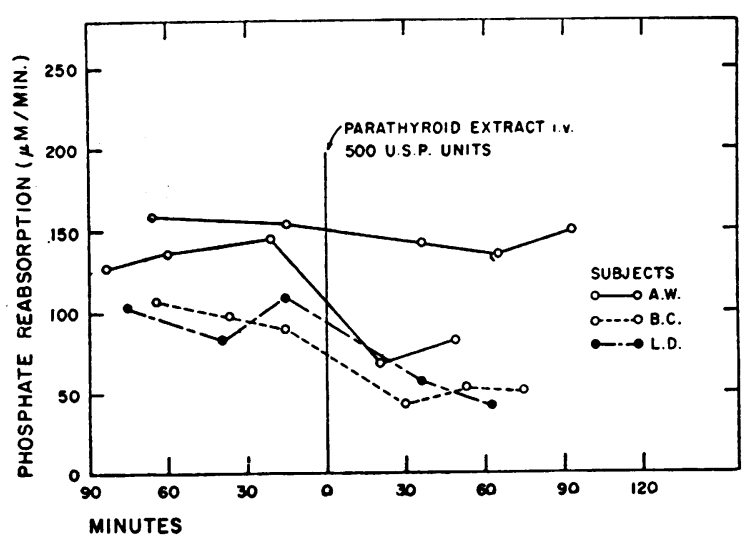

Fig. 4. Changes in TmP Following the Administration of Parathyrom Extract to Three Subjects WITH HYPOPARATH YROIDISM 
TABLE VI

ACUTE EFFECTS OF INTRAYENOUS PARATHYROID EXTRACT ON REMAL FUNCTION IN HYPOPARATHYROIDISM

\begin{tabular}{|c|c|c|c|c|c|c|c|c|c|c|c|}
\hline \multirow[b]{2}{*}{ Deve } & \multirow[b]{2}{*}{ Subject } & \multirow{2}{*}{$\begin{array}{l}\text { Units } \\
\text { of } \\
\text { Extrect }\end{array}$} & \multicolumn{3}{|c|}{$C_{\text {PAH }}$} & \multicolumn{3}{|c|}{$C_{W}$} & \multicolumn{3}{|c|}{$T m P$} \\
\hline & & & $\begin{array}{l}\text { Before } \\
\text { ml/min. }\end{array}$ & $\begin{array}{c}\text { Afree } \\
\text { molmin. }\end{array}$ & $\begin{array}{l}\text { Poreent } \\
\text { Chonge }\end{array}$ & $\begin{array}{l}\text { Before } \\
\text { nil/min. }\end{array}$ & $\begin{array}{l}\text { Afrer } \\
\text { ml/min. }\end{array}$ & $\begin{array}{l}\text { Pereent } \\
\text { Chease }\end{array}$ & $\begin{array}{l}\text { 3eforo } \\
\text { miM/min. }\end{array}$ & $\begin{array}{c}\text { Afrer } \\
\text { nin/mia. }\end{array}$ & $\begin{array}{l}\text { Pereenes } \\
\text { Chenge }\end{array}$ \\
\hline $8 / 25 / 54$ & A. W. & 500 & & & & $\%$ & 103 & +7 & 158 & 142 & -10 \\
\hline $2 / 25 / 55$ & A. W. & 500 & 498 & 852 & $+\pi$ & 108 & 113 & +5 & 137 & 75 & -15 \\
\hline $2 / 22 / 55$ & B. C. & 500 & 230 & 418 & +75 & 63 & 69 & +10 & 98 & so & - 49 \\
\hline $3 / 9 / 55$ & L D. & 500 & 325 & 668 & +102 & 75 & 87 & +16 & 9 & S1 & -40 \\
\hline
\end{tabular}

\section{TABLE VII}

EFFECTS OF PROLONGED ADMINSTRATION OF PARATHYROID EXTRACT ON PLASMA AND URIMARY CALCLGM AND PHOSPHORUS

\begin{tabular}{|c|c|c|c|c|c|c|c|c|c|c|}
\hline \multirow{2}{*}{ Subject } & \multirow{2}{*}{$\begin{array}{l}\text { Total } \\
\text { Units of } \\
\text { Extrect }\end{array}$} & \multirow{2}{*}{$\begin{array}{c}\text { Hours of } \\
\text { Administrotion }\end{array}$} & \multicolumn{2}{|c|}{$\begin{array}{l}\text { Plosmo Co } \\
\text { mg. percent }\end{array}$} & \multicolumn{2}{|c|}{$\begin{array}{l}\text { Plosmo P } \\
\text { MM/mi }\end{array}$} & \multicolumn{2}{|c|}{$\begin{array}{l}\text { Urine Co } \\
\text { Mgm/min. }\end{array}$} & \multicolumn{2}{|c|}{$\begin{array}{l}\text { Urine } P \\
\text { palimian }\end{array}$} \\
\hline & & & Before & After & Befere & After & Before & Afrer & Before & Alver \\
\hline Nenmel & & & & & & & & & & \\
\hline C. H. $7 / 13 / 54$ & 4000 & 60 & 9.80 & 13.50 & 1.23 & 1.02 & & & 9 & $\boldsymbol{5 2}$ \\
\hline W. R. $8 / 19 / 54$ & 4500 & 72 & 10.02 & 13.90 & 0.96 & 0.73 & & & 23 & $\boldsymbol{s 2}$ \\
\hline W. R. $5 / 6 / 55$ & 4000 & 72 & 9.40 & 15.20 & 0.98 & 0.63 & 200 & 120 & 7 & $\boldsymbol{x}$ \\
\hline E.P. $3 / 31 / 55$ & 2500 & 120 & 10.60 & 12.90 & 1.17 & 068 & 213 & SOS & 8 & 20 \\
\hline L. 8. $11 / 22 / 54$ & 2100 & 72 & 9.20 & 12.00 & 0.90 & 0.70 & 257 & $M$ & 16 & 24 \\
\hline W. H. $10 / 22 / 54$ & 1800 & 66 & 860 & 11.31 & 1.23 & $a . x$ & 161 & 212 & 9 & 25 \\
\hline Hypoperesthyroid & & & & & & & & & & \\
\hline A. W. $9 / 30 / 54$ & 3000 & 9 & 7.10 & 12.90 & 1.42 & a.cs & 3 & $\boldsymbol{\varphi}$ & a.9 & 21 \\
\hline B. C. $2 / 24 / 54$ & 2500 & 60 & 8.08 & 11.95 & 1.35 & 0.74 & & & & \\
\hline
\end{tabular}

\section{TABLE VIII}

RENAL EXCRETION OF PHOSPHATE BEFORE (A) AND AFTER (B) ADMIMISTRATION OF ISOO USP UNITS OF PARATHYROID EXTRACT DALY FOR 3 DAYS

\begin{tabular}{|c|c|c|c|c|c|c|c|}
\hline & \multirow{2}{*}{$\begin{array}{l}\text { ELAPSED } \\
\text { TIME } \\
\text { Min. }\end{array}$} & \multirow[b]{2}{*}{$\begin{array}{l}C_{\text {PAH }} \\
\mathrm{ml} / \mathrm{min} .\end{array}$} & \multirow[b]{2}{*}{$\begin{array}{c}C_{\mathbb{I N}} \\
m l / \min .\end{array}$} & \multirow[b]{2}{*}{$\begin{array}{l}\text { PLASMA P } \\
\mu M / m l .\end{array}$} & \multicolumn{3}{|c|}{ PHOSPHATE } \\
\hline & & & & & $\begin{array}{l}\text { FILTERED } \\
\mu M / \min \end{array}$ & $\begin{array}{c}\text { EXCRETED } \\
\mathrm{M} / \mathrm{min} .\end{array}$ & $\begin{array}{l}\text { REABSORBED } \\
\mathrm{m} / \mathrm{M} / \mathrm{min} .\end{array}$ \\
\hline \multirow[t]{3}{*}{$A$} & $80-109$ & 570 & 100 & 2.43 & 213 & 104 & 139 \\
\hline & $109-139$ & 580 & 102 & 2.74 & 279 & 143 & 136 \\
\hline & $139-169$ & 555 & 106 & 3.05 & 324 & 181 & 143 \\
\hline \multirow[t]{3}{*}{ B } & $183-222$ & 684 & 124 & 2.36 & 292 & 214 & 78 \\
\hline & $222-243$ & 665 & 107 & 2.61 & 279 & 225 & S4 \\
\hline & $266-293$ & 576 & 111 & 2.33 & 259 & 213 & 46 \\
\hline
\end{tabular}

W. R. 22 yeor old normal male.

Continuous infusion of buffered sodium phosphote and iaulia.

rise in filtered phosphate. In hypoparathyroid subjects the relative increase in phosphate excretion is even more striking, for in such individuals parathyroid extract produces not only a rise in filtration rate, but a depression of tubular reabsorption of phosphate as well. Repeated subcu- 
TABLE IX

REMAL EXCRETION OF PHOSPHATE BEFORE (A) AND AFTER (B) ADMUMSTRATION OF 900 USP UNITS OF PARATHYROID EXTRACT DALY FOR 3 DAYS

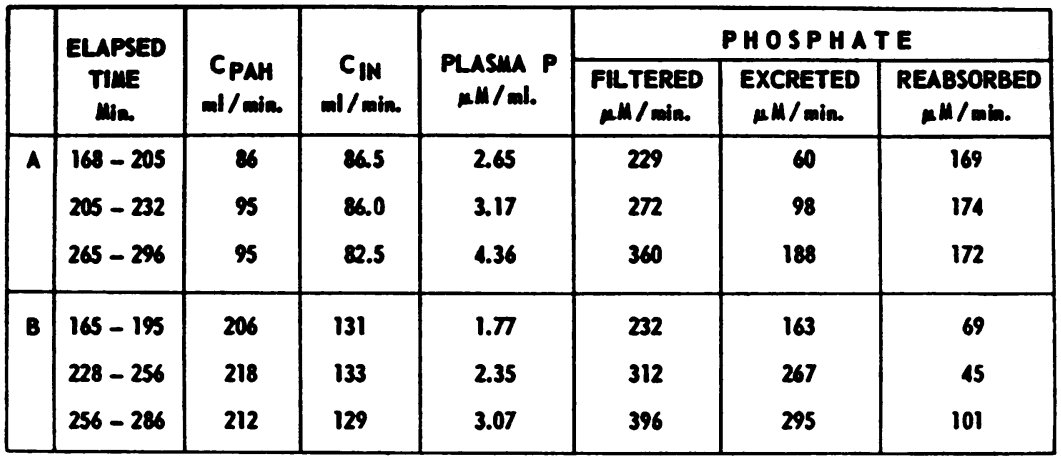

A. W., 37 yeer old hypoperethyroid mole.

Continuous infusion of inulin and buffered sodium phosphote.

TABLE X

EFFECTS OF PROLONGED ADMMASTRATION OF PARATHYROID EXTRACT ON RENAL FUACTION

\begin{tabular}{|c|c|c|c|c|c|c|c|c|c|c|c|}
\hline \multirow[b]{2}{*}{ Subject } & \multirow{2}{*}{$\begin{array}{l}\text { Tovel } \\
\text { Chairs of } \\
\text { Entreet }\end{array}$} & \multirow{2}{*}{$\begin{array}{l}\text { Howss of } \\
\text { Admini atrotion }\end{array}$} & \multicolumn{3}{|c|}{$C_{\text {PAH }}$} & \multicolumn{3}{|c|}{$C_{\text {IN }}$} & \multicolumn{3}{|c|}{$T \backsim P$} \\
\hline & & & $\begin{array}{l}\text { Before } \\
\mathrm{ml} / \mathrm{min} \text {. }\end{array}$ & $\begin{array}{c}\text { Affer } \\
\mathrm{ml} / \text { min. }\end{array}$ & $\begin{array}{l}\text { Pereent. } \\
\text { Chenge: }\end{array}$ & $\begin{array}{l}\text { Before } \\
\mathrm{ml} / \mathrm{min} \text {. }\end{array}$ & $\begin{array}{c}\text { After } \\
\mathrm{ml} / \text { min. }\end{array}$ & $\begin{array}{l}\text { Pereent } \\
\text { Chenge }\end{array}$ & \begin{tabular}{|c|} 
Before \\
Mullmin.
\end{tabular} & $\begin{array}{c}\text { Afrer } \\
\text { MM/min. }\end{array}$ & $\begin{array}{l}\text { Pereent } \\
\text { Chene }\end{array}$ \\
\hline \multicolumn{12}{|l|}{ Nomel } \\
\hline C. H. $7 / 13 / 54$ & 4000 & 60 & 550 & 763 & +39 & 135 & $|5|$ & +12 & 200 & 138 & -31 \\
\hline W. R. $8 / 19 / 54$ & 4500 & $\boldsymbol{n}$ & 585 & 728 & +24 & 113 & 121 & +7 & 122 & 63 & -4 \\
\hline W. R. $5 / 6 / 55$ & 4000 & $\boldsymbol{7}$ & 558 & 568 & +2 & 102 & 95 & -7 & 8 & 29 & -4 \\
\hline E. P. $3 / 31 / 55$ & 2500 & 120 & 537 & 430 & -20 & 96 & 85 & -11 & 110 & 4 & -4 \\
\hline L. B. $11 / 22 / 54$ & 2100 & 72 & 846 & 837 & -1 & 136 & 131 & -4 & 124 & $\boldsymbol{n}$ & -27 \\
\hline W. H. $10 / 22 / 54$ & 1800 & 66 & 904 & 899 & -2 & 125 & 129 & +3 & 179 & 118 & -3 \\
\hline \multicolumn{12}{|l|}{ Hrenemenomold } \\
\hline A. $1.9 / 30 / 54$ & 2700 & $\boldsymbol{n}$ & 157 & 200 & +27 & $\%$ & 129 & $+\mathbf{3}$ & 175 & $\boldsymbol{n}$ & -99 \\
\hline a. C. $2 / 24 / 54$ & 2500 & 60 & 236 & 232 & -2 & $\pi$ & 57 & -23 & |31 & ss & -57 \\
\hline
\end{tabular}

taneous administration of extract, however, both to normal and to hypoparathyroid subjects induces a state of hyperparathyroidism, characterized by an invariable and striking diminution in TmP. No effort was made to determine the minimal period of extract administration required before a tubular effect is demonstrable in normal individuals; sixty hours was the shortest duration of an experiment involving the subcutaneous administration of hormone, and a 31 per cent decrease in $\mathrm{TmP}$ was observed. Why the tubular effect is more readily demonstrable in the hypoparathyroid than in the normal individual is unknown, but this phenomenon may have a parallel in the increased sensitivity to small amounts of thyroid noted in patients with myxedema (13).

Of considerable interest is the fact that the induced hyperparathyroid state in several of our subjects was not accompanied by a rise in GFR or in RPF. These observations strengthen the thesis that the factor in parathyroid extract exerting an action on renal hemodynamics is distinct from the hormonal principle(s) responsible for hypercalcemia and a reduction in TmP. While our data support the concept that the phosphaturia seen in normal subjects immediately after the intravenous administration of $\mathrm{PTH}$ is not the result of changes in renal tubular transport of phosphate, they also demonstrate that under appropriate conditions tubular reabsorption of phosphate is profoundly inhibited by the hormone. Similar findings have been noted in the dog by Handler and Cohn (14).

The fact that prolonged administration of the extract is required to depress $\mathrm{TmP}$ in normal individuals raises the question as to whether the 
TABLE XI

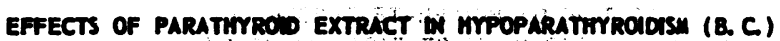

\begin{tabular}{|c|c|c|c|c|c|c|c|c|c|c|}
\hline \multirow{2}{*}{ Dare } & \multirow{2}{*}{$\begin{array}{l}\text { Penethyoid } \\
\text { Exprest }\end{array}$} & \multirow{2}{*}{$\underset{\substack{\text { Elopeod } \\
\text { Time }}}{ }$} & \multirow{2}{*}{$\begin{array}{l}\text { Uniwo } \\
\text { Flow } \\
\text { milatici }\end{array}$} & \multirow{2}{*}{$\mid \begin{array}{c}\text { Plowa } \\
\text { Co } \\
0\end{array}$} & \multirow{2}{*}{ 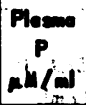 } & \multirow{2}{*}{$\begin{array}{l}C_{\text {PAH }} \\
\text { 'l/min. }\end{array}$} & \multirow{2}{*}{$\begin{array}{c}C_{\mathbb{I N}} \\
\text { il/min. }\end{array}$} & \multicolumn{3}{|c|}{ Pheaphove (aM/mina) } \\
\hline & & & & & & & & Filteved & Exerened & Reebseated \\
\hline $2 / 9 / 55$ & Nem & $\begin{array}{c}0 \\
26 \mathrm{Ce} \\
89-121 \\
121-153 \\
153-190\end{array}$ & $\begin{array}{l}6.85 \\
8.07 \\
7.81\end{array}$ & $\begin{array}{l}800 \\
7.40 \\
5.36\end{array}$ & $\begin{array}{l}1.35 \\
\text { inolition } \\
3.33 \\
3.73 \\
4.00 .\end{array}$ & $\begin{array}{l}252 \\
234 \\
222\end{array}$ & $\begin{array}{l}75.5 \\
73.6 \\
\pi .5\end{array}$ & $\begin{array}{l}252 \\
274 \\
266\end{array}$ & $\begin{array}{l}114 \\
143 \\
161\end{array}$ & $\begin{array}{l}138 \\
131 \\
125\end{array}$ \\
\hline & & meon & & . & & 236 & 73.5 & $2 \pi$ & 139 & 132 \\
\hline $2 / 14 / 55$ & $\begin{array}{l}50 \mathrm{ub} \text { bid } \\
\text { for } 3 \text { doyes }\end{array}$ & $\begin{array}{c}0 \\
26 C_{0} \\
93-124 \\
124-157 \\
157-187\end{array}$ & \begin{tabular}{|l|}
.32 \\
8.82 \\
9.40
\end{tabular} & \begin{tabular}{|l}
7.56 \\
7.09 \\
6.83
\end{tabular} & $\begin{array}{l}0.91 \\
\text { incliais } \\
2.62 \\
2.94 \\
3.32\end{array}$ & $\begin{array}{l}H_{1} \text { and } \\
266 \\
265 \\
258\end{array}$ & $\begin{array}{l}84.0 \\
82.9 \\
83.3\end{array}$ & $\begin{array}{l}224 \\
2 \pi \\
2 \pi\end{array}$ & $\begin{array}{l}131 \\
106 \\
194\end{array}$ & $\begin{array}{l}93 \\
78 \\
83\end{array}$ \\
\hline & & Moen & & & & 259 & 83.4 & 248 & $\mathbf{M A}$ & 85 \\
\hline $2 / 24 / 55$ & $\begin{array}{l}5000.4 \\
12 \text { bo. } 5 \text { 5i.ve }\end{array}$ & $\begin{array}{c}0 \\
109 c \\
173-205 \\
215-241 \\
241-270\end{array}$ & \begin{tabular}{|l|}
3.41 \\
3.65 \\
4.01
\end{tabular} & $\begin{array}{l}\text { I11.95 } \\
\text { inforien } \\
\mid\end{array}$ & $\begin{array}{l}0.74 \\
\text { indin, } \\
2.57 \\
3.08 \\
3.52\end{array}$ & $\begin{array}{c}\text { PAH, and } \\
220 \\
225 \\
252\end{array}$ & $\begin{array}{l}\text { hospher } \\
55.7 \\
56.5\end{array}$ & $\begin{array}{l}148 \\
163 \\
199\end{array}$ & $\begin{array}{c}n 8 \\
113 \\
137\end{array}$ & $\begin{array}{l}50 \\
55 \\
02\end{array}$ \\
\hline & & Mnen & & & & 292 & 36.6 & 17 & 116 & E6 \\
\hline
\end{tabular}

hormone acts directly on the renal tubule. That the hypercalcemia produced by the hormone is not responsible for the change in tubular transport of $\mathrm{P}$ is indicated by the demonstration that a rise in plasma $\mathrm{Ca}$ leads to an increase in the tubular reabsorption of $P$ (15). In addition, the prompt and striking fall in TmP which follows the intravenous administration of parathyroid extract to

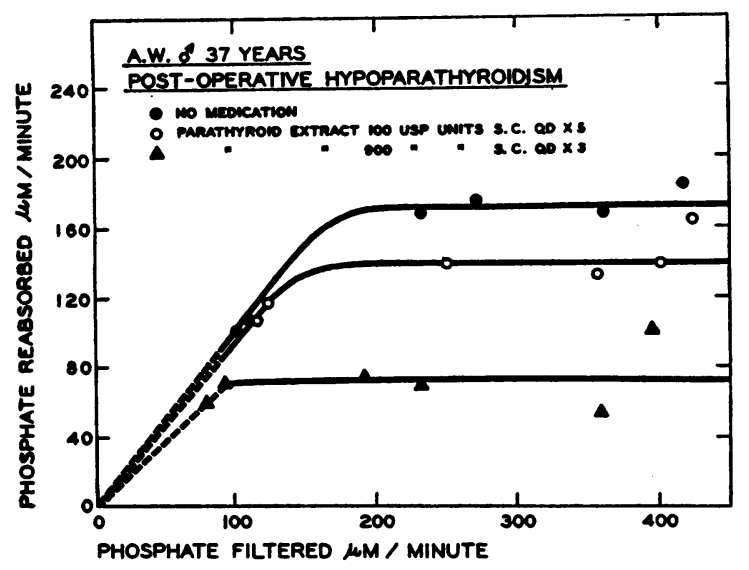

Fig. 5. Tubular Reabsorption of Phosphate at Several Levers of Fintered Phosphate in a HypoparathyroId SUbJect in the UNTreated State, IN AN "Isoparathyrom" State, aNd IN A HYPERparathyroId State hypoparathyroid subjects strongly suggests a direct effect of the hormone on the renal tubule.

No manifestations of hyperparathyroidism were observed in W. R. following the intravenous administration of 1500 units of extract over a sixhour period on each of three successive days. Whether the renal tubule and bone of the normal individual must be constantly exposed to the extract for an even more prolonged period of time before a change in $\mathrm{TmP}$ or in calcium metabolism is demonstrable remains to be answered.

The demonstration of an action of PTH on the kidney does not, of course, exclude an effect on bone. Indeed, only by invoking an action of the hormone at both sites can one satisfactorily explain the chemical aberrations characteristic of patients with hyperparathyroidism. It would appear reasonable, then, to assume that the secretion(s) of the parathyroid alters metabolic processes in bone, in kidney, and possibly even elsewhere.

\section{SUMMARY}

1. The intravenous administration of parathyroid extract results in a phosphate diuresis. Such an effect in normal subjects can generally be accounted for by a rise in filtered phosphate secondary to a rise in glomerular filtration rate with- 
out any decrease in phosphate $\mathrm{Tm}$. In hypoparathyroid individuals there is a diminution in the tubular reabsorption of phosphate as well as an increase in filtered phosphate.

2. Repeated subcutaneous injections of parathyroid extract both to normal and to hypoparathyroid individuals lead to a diminution in the maximal tubular reabsorptive capacity for phosphate.

3. The phosphaturia seen after the acute administration of extract to normal individuals is usually caused by an action of the extract on renal hemodynamics and is not accompanied by hypercalcemia. Following the prolonged administration of parathyroid extract to normal individuals, however, hypercalcemia is observed as well as a decrease in $\mathrm{TmP}$, but without any constant change in renal hemodynamics.

\section{ACKNOWLEDGMENT}

We wish to express our gratitude to Misses Mary Margaret Brown and Doris Graves for their technical assistance.

\section{REFERENCES}

1. Barnicot, N. A., The local action of the parathyroid and other tissues on bone in intracerebral grafts. J. Anat., 1948, 82, 233.

2. Chang, H.-Y., Grafts of parathyroid and other tissues to bone. Anat. Record, 1951, 111, 23.

3. Grollman, A., The role of the kidney in the parathyroid control of the blood calcium as determined by studies on the nephrectomized dog. Endocrinology, 1954, 55, 166.

4. Greenwald, I., and Gross, J., The effect of the administration of a potent parathyroid extract upon the excretion of nitrogen, phosphorus, calcium, and magnesium, with some remarks on the solubility of calcium phosphate in serum and on the pathogenesis of tetany. J. Biol. Chem., 1925, 66, 217.

5. Albright, F., Bauer, W., Ropes, M., and Aub, J. C., Studies of calcium and phosphorus metabolism. IV. The effect of the parathyroid hormone. J. Clin. Invest., 1929, 7, 139.

6. Thompson, D. D., and Hiatt, H. H., Renal reabsorption of phosphate in normal human subjects and in patients with parathyroid disease. J. Clin. Invest., 1957, 36, 550.

7. Merrill, A. J., and Cargill, W. H., The effect of exercise on the renal plasma flow and filtration rate of normal and cardiac subjects. J. Clin. Invest., 1948, 27, 272.

8. Bartter, F. C., The parathyroids. Ann. Rev. Physiol., 1954, 16, 429.

9. Jahan, I., and Pitts, R. F., Effect of parathyroid on renal tubular reabsorption of phosphate and calcium. Am. J. Physiol., 1948, 155, 42.

10. Handler, P., DeMaria, W. J. A., and Cohn, D. V., Mode of action of parathormone. Federation Proc., 1949, 8, 204.

11. Hogben, C. A. M., and Bollman, J. L., Renal reabsorption of phosphate: normal and thyroparathyroidectomized dog. Am. J. Physiol., 1951, 164, 670.

12. Stewart, G. S., and Bowen, H. F., The urinary phosphate excretion factor of parathyroid gland extracts: A hormone or an artefact? Endocrinology, 1952, 51, 80.

13. Means, J. H., The Thyroid and Its Diseases. 2nd ed., Philadelphia, J. B. Lippincott Co., 1948.

14. Handler, P., and Cohn, D. V., Effect of parathyroid extract on renal function. Am. J. Physiol., 1952, $169,188$.

15. Hiatt, H. H., and Thompson, D. D., Some effects of intravenously administered calcium on inorganic phosphate metabolism. J. Clin. Invest., 1957, 36, 573.

\section{SPECIAL NOTICE TO SUBSCRIBERS}

Post Offices will no longer forward the Journal when you move.

Please notify The Journal of Clinical Investigation, Business Office, 622 West 168th Street, New York 32, N. Y. at once when you have a change of address, and do not omit the zone number if there is one. 